Portland State University

PDXScholar

1975

\title{
A Comparison of Socialization and the Current Attitudes Towards Personal and Feminist Issues of Women Over 65
}

Gayle Austin

Portland State University

Anna Belle Sime

Portland State University

Follow this and additional works at: https://pdxscholar.library.pdx.edu/open_access_etds

Part of the Other Feminist, Gender, and Sexuality Studies Commons, and the Women's Studies Commons

Let us know how access to this document benefits you.

\section{Recommended Citation}

Austin, Gayle and Sime, Anna Belle, "A Comparison of Socialization and the Current Attitudes Towards Personal and Feminist Issues of Women Over 65" (1975). Dissertations and Theses. Paper 2178. https://doi.org/10.15760/etd.2175

This Thesis is brought to you for free and open access. It has been accepted for inclusion in Dissertations and Theses by an authorized administrator of PDXScholar. Please contact us if we can make this document more accessible: pdxscholar@pdx.edu. 
A COMPARISON OF SOCIAIIZATION AND THE CURREMI ATMITUDES

TOWARDS PERSOLAL AND FEMINIST ISSUES OF WOMHW OVER 65

\author{
by \\ GAYLE AUSIIN \\ and \\ ANNA BEILE SIME
}

A research practicum in partial fulfillment of the requirements for the degree of

MASTER OF SOCIAL WORK

Portland State University

1975

Advisor:

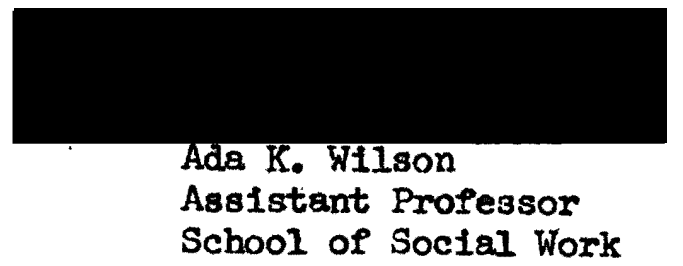


CHAPTER

PAGE

I

INTRODUCTION, . . . . . . . . . .

II

METHODOLOGI . . . . . . . . . . .

A. DATA COLLECmON. . .......

Pretest

Population and Sample

B. THE QUESTIONNAIRE. . . . . .

Rellability

Description of the Questionnaire

III

ANALYSIS OF QUESTIONIAIRE RESULTS . . . .

A. THE CATEGORIZED VARTABLES. . . .

The Dependent Variables

Summary

B. THE INDEPENDEIFT VARTABLES. - • -

15

C. THE COMPOSITE RETATIONSHIPS. . . 15

IV SUMMARI AND COIKCLGSIONS . . . . . . 25

SELECTED BIBLIOCRAPHY . . . . . . . . . . . 29

APPENDIX A . . . . . . . . . . . . 31

APPEHDIX B . . . . . . . . . . . . . 35 
CEAPIER I

\section{MinRODUCHION}

Women, as feminista and as fandlists, bave been in mang varied ways the subjects for study. They bave been studied as black ronen, middle-aged women, sexual women, women in povexty, wowen in prison, romen raped, executives, celebrit1es, lesblans, and bonewhere. The cleselflcations and coubinations epproech infinity. For older womon are becoming a inore popular research tople, as their numbers increase with medical attainnerits. With the Increasing participation of older "sisters" in such organizations as the National Organization for Wowen, and the advent of groups such as the Gray Panthers, it has becone apparent that there are no age barriers to fominism. "SInce sexisn pervades our ent1re soclety from cradle to grave there are fominist issues for all ages. Wonen, as well as men, take sides on all of them." ${ }^{1}$ still, a survey of the literature indicates a dearth of research on the combination: older women and feminism. A series of questions led us to our topic. What vill ow attitudes on the Is8ues now personally significant be in 40 years, when we heve pasped "ret1rement age?" What vere vomen who heve reached this age 11ke when they vere our age and jounger?

1. Bernard, Jesse, "Age, Sex, and Fenintsm;" The Annsls of the Amerlcan Acadeur of Polltical and Soctal Sclence, Vol. 415 (September 1974), p. 127. 
Is there a connection between their younger years and the attitudes they now possess? In purwuing this final question we chose to define the "younger years" as before 25, when soclalization Influences one's search for ldentity, development of autonous, and developnent of internal criteria for self-esteen. The age chosen for our population wes after the 65 th birthday, when most vomen are no longer voring. outside of the home for wages.

We used Bardrick and Douvan's. definition for socialization: "the pressures--rewarding, puniahing, Ignoring, and antlcipating--that push the chlld toward evoking icceptable responses." 2 These are the pressures, Individualized by degree, to murture, obey, be responstble, achieve, and/or rely upon oneself. These early pressures would be difficult to measire considering our chosen population. Those subtle influences are not with ease accurately recalled. The results of pressures and encouragement lend themselves to both recollection and measurement. The individual activities and family of girihood became our indicators of socialization.

We sought, the first half of our questlonnaire, to measure the Independence, assertiveness, and analytic-aindedness of the woman in her younger years. We asked questlons about the woman's parents and her own marriage and fantly. The second half of the questlonnalre was designed to measure the woman's present attitudes of feminist Issues and her attitudes toward her orn fanily and personal iffe.

2. Batarick, Judith M. and Elizabeth Douvan, "Ambivalence: the Socialization of Women," Gornick, V. and B.K. Moran (editors), Woman in Sexist Society,

Hew Ióx: Basic Books, Inc., 197, p. 226. 
It has been said that women who bave achleved and have been rewarded for their achievements cannot accept traditional roles. Such roles do not gratify their non-aurturant, non-supportive, non-dependent, non-passive aspects of their selves. ${ }^{3}$ Our bypotheses were made in accordance: that a woman's "feninism," as, measured by our scale, would be directly related to her level of achlevenent in school and in work, her leadershlp or participation in religious activities, politics, and sports. In addition to the above objectives, we wanted to seek a relationship between the woman's fominism score and other aspects of her fanily background, her inter-relationships with boys, and her opportunities to travel. We approached these Issues without hypotheses, but with great recoptivity and interest.

3. Tb1d., p. 235 . 
CHAPIYR II

MEIHIODOLOCY

A. DALA COLFBCTION

Pretest. The first step in our data collection Involved distributing our questionnaire to nine vomen acqualntances who served as our pretest population.

After the pretest was conducted, seroral questions were modifled or eliminated because they were elther confusing, vague or irrelevant. Two of the open-ended questlions were elininated because of the difficulty involved in coding their responses and the questioneble use of the information.

We checked the muber of undectded responses in part two of the questionnaire and changed those statements accordingly to make room for a clearer understanding of the statements.

After the questionnolre was anowered by each participant in our pretest population it was discussed for comments.

Population and Sample. The population consisted of 50 women aged 65 and older who live in the greater Portland area. The sample 1s representative of differing income levels. The 50 women who participated in our study vere volunteers from five different senfor adult groups.

At the Jewish Community Center the majority of our participants was Jewish. The parents of many and some of the women had lived in Russia or Finland. 
The Jew1sh Communtty Center serves the lelsure hours of nembers with atblet1c, cultural, social, and educational prograns. Members from preschool age through sentor adults take part in a variety of activities including physical education, owiming, a health club, Interest classes for all age groups, gameroom and lounges, and spectal programing for sentor adults. The hydrotherapy program bas served those in physical noed for over 40 years. The Jewish Comountty Center's resident camp, B'nal B'rith Canp, has special programs for senior adults.

The membership fee is baged on fanily composition. The anmual membership fee for the total fantly is $\$ 200.00$ and for older persons it is an indiridual fee.

The Jerlsh Comminity Center's source of income comes from the Jewish Welfare Federation, menbermhlp fees, other Income, and United Good Ne1ghbors.

Services for senfor adults offered by Lake Oswego Adult Comminity Center laclude soclal, recreational, and educational classes and activities, transportation to the center, tours, shopping, etc., hot meals, outreach volunteer opportunities, information and referral. Fursing home visitation and health clinte are also offered.

To be ellgible the Individual must be 50 years and above. There is no membership fee but donations are appreclated. There are nominal charges for specific services. The source of support for Lake Oswego Adult Community Center 
cames from the city of Lake Oovego, contribut1ons, and federal funds (Administration on Aging).

At Holladay Park Plaza, people 62 years of age and over are eligtble to apply for residency. At thls particular retirement home, there is a 90-day "trial period" in which the resident has the opportunity to see whether or not life at Holladay Park PIaza will fulpill bis or her hopes.

The wonthly charge at Holladay Park Plaze 18 based on actual operating costs. The site is a private residence providing meals, ut1lities, mald and lipen service, building and grounds upkeep, recreational facilities, 24-hour. switchboard service and the use of the health-care center. The monthly charge may run $\$ 186.00$ for one person and $\$ 331.00$ for two people. In addition, the entrance fee at Holladay Park Plaza is approximately $\$ 11,800$ but the foe varles according to the type, size, and location of the apartment unit and the meal plan selocted.

Loaves and Flighes offers a low-cost mutritional mid-day meal at 34 meal centers, most of which also deliver meals to homebound elderly at the same "pay as you can" rates. There are also opportunfties for recreation and fellowshlp at these centers. Angone who is 60 years of age or over is eligible to attend Loeves and Fishes's luncheons.

Ioaves and Flshes's source of support Includes churches, conmunity organizations, donations, Housing Authority of Portland, 
and federal funds.

Our sample was taken from a Ioaves and Flshes center located In a Housing Autbority epartwent building In north Portiand. Marshall Center is operated through the Departwent of Parke and Recreation In Vancourer, Washington, and it is a multi-nodia recreationsl center for all ages. For senior adults, Naraball Center offers a wide range of soclal and recreational opportunities, such as potlucks, dances, card ganes, bllliards, dance and wrimenting 1essons.

Our sample from Marshall Center was taken from a group of briage players who neet veekly.

With the exception of Holladay Park PLaza, where our queationnaire was distributed to 18 people by the Coordinator of Activities following our verbal instructlons, we vere initially introduced to the senfor groups by the host or hostess as graduate students from Portland State University School of Social Work. We explained briefly our study and then asked for volunteers. We asked our volunteers to remain anowymous.

We encountered resistance on the part of sore rolunteers. A fer began answering the questionnaire but changed their minds later and returned it to us. We offered some assistance to the visually Impaired and to those who found it difficult to follow Instructions. 
B. THE QUESTIORMAIRE*

Rellabllity. Obviously ambiguous questions were eliminated after the pretest. Independent variables afforded checks of Internal consistency, found satisfactory in all cases. Statistical measures of rellability and valldity were not used.

Description of the Questionnalie. The questionnalre consiated of 50 questions and was divided into two parts, the first part of which dealt with family background and the sociallzation process before the age of 25 . Most of the questions were structured but some were unstructired.

The second part of the questionnaire was an attitude scale of 24 statements, phrased positively and negatively and balanced between self-oriented and family-oriented statements.

In developing this second part we used questlonnaires from other feminist studies, modifying some of their statements while adding some of our orn original statements. These statements covered both basic and current issues of concern to vomen.

* See Appendix A for a copy of the questionnaire. 


\section{CHAPLUR III}

\section{ATALNSIS OF QUESTIOTIAIRE RESULMS}

\section{A. THE CAIMBORIZIFD VARTABIES}

The Dependent Vartables

The dependent variable used in seeking correlation with the independent variables was the composite score achieved on the feminlst attitude scale (Intensity and degree) by sample. These scores vere divided into two evenly mubered groups according to whether they were above or beloi the median score.

The statements, as described in the nethodology, were of three orlentations, and split into three categories. Category one statements related to speciflc soctal and personal 1seues. These are the 18sues which make news--1ssues regarding woman's role in soclety. Some have been discussed emotionally for sereral years and have been brought out politically in recent months. For instance, funds for day-care centers have been recently cut, sending wany wowen who are heads of their households to the welfare rolls, and wives back to homemaking because thelr incones are no longer sufficleut to pay for dey-care for thelr children. Rape has been a legislative issue in Oregon this year with a bill which would eliminate the use of a woman's past sexual experience as evidence by the defendant's attorneys. Wowen are suing against discrimination 
by creditors, and last year a dozen wonen were not long ordained as Eplscopalian priests before they were de-ordained.

TABLE I

MEAN SCORES FOR ALL WOMET FOR AISWERS TO CALEGORI I QUESTIOMS

I see a great need for Inexpensive day care

centers for chlldren.

$n=$

Mean Score

It's usually the woman's fault if she is raped. 45

3.34

Women don't need to have credit in their orn

names if they are married.

49

2.95

I don't belleve women should be clergy.

43

2.83

Woman's imge in the media overly

emphasizes beauty, fashions, and home-making

virtues.

44

2.70

Boys have a greater need for athlet1c programs In school than do girls.

47

2.53

Single women should have the cholce to bear

and/or adopt children without social rejection. $41 \quad 2.39$

We need more women politiclans.

$\frac{43}{n=356} \quad 2.22$

Mean score for Category I quest1ons: 2.87

Issues of this category brought out the strongest feminfst scoring. The four above mentioned issues--day-care, rape, credit, and clergy, In that order-were given the strongest responses in the category. Within the category, the statement "We need more women politicians" was the most undeclded upon, and drew the lowest score from those 
who were decided. The 1ssues, in varying degrees all political, appear to be more important than who decides upon them.

Category two statewents ellcited responses to issues regarding marriage and motherhood, Including issues of inter-relationships between work and family responsibility.

TABIE II

MEAN SCORTS FOR AIL WOMEN FOR AISWERS TO CATEGORY 2 QUESTIONS

Child ralsing should be an equally shared

responstbility of husband and vife.

$n=$

Mean score

Wives should share equally with their

husbands in making fantly financial dec1sions. 49

3.34

Euplojed tomen probably have less satisfylng

marriages.

38

2.86

For a wowan nowadays, it is marrlage which gives her her sense of Identity and a regpected place in society.

2.77

A working mother can establish just as strong and secure a relationship with her children as can a stay-at-howe mother.

A marriage can be very complete without children.

44

2.75

Husbands should carn more money than their wives.

40

2.22

A woman can make no greatex contribution to society than the successful rearing of normal, well-adjusted chlldren.

$\frac{46}{n=356} \quad 1.7$

Meen score for Category 2 questions: 2.72 
12

Two particular statements, "Wives should share equally with their husbands in making family financial decisions," and "Child raising should be an equally shared responsibility of husband and wife" both evoked very high scores and only one "undecided" response. It may be pointed out that they were the only two in the category (and for that matter, in all three categories) which used the word "equally."

The statement "A woman can make no greater contribution to society than the successful rearing of normal, well-adjusted children" scored, by a wide margin, the lowest of and statement in all categories.

Category three statements related to personal issues including self-realization. 
TABIE III

MEAN SCORES FOR AIT WOMEN FOR ANSWERS TO CATEGORY 3 QUESTIONS

\begin{tabular}{|c|c|c|}
\hline 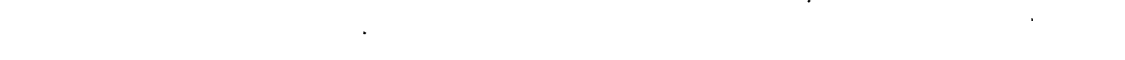 & $n=$ & Mean Score \\
\hline $\begin{array}{l}\text { Education is as important for women as for men. } \\
\text { I am more concerned with wy personal development than } \\
\text { I am with the approval of others. }\end{array}$ & 44 & 3.38 \\
\hline $\begin{array}{l}\text { Women do not think as logically as men. } \\
\text { Women are much better off than men in this society } \\
\text { because they have protection, leisure, and freedom } \\
\text { from pressures to achieve. }\end{array}$ & 42 & 2.97 \\
\hline $\begin{array}{l}\text { Women in the Women's Iiberation Movement are } \\
\text { well-adjusted women with justifiable causes. }\end{array}$ & 35 & 2.51 \\
\hline Women are more emotional than men. & 46 & 2.23 \\
\hline Women are conditioned to hide their intelligence. & 46 & 2.21 \\
\hline $\begin{array}{l}\text { Militant efforts for women's rights will do more } \\
\text { harm than good. }\end{array}$ & $\frac{44}{n=348}$ & 2.10 \\
\hline Mean scores for Category 3 questIons: 2.63 & & \\
\hline
\end{tabular}

The category's mean score was the lowest of the three, and the number of "undecided" responses was highest. It did, however, Include the one statement on which no woman was undecided, and with which only two women disagreed: "Education is as important for vonien as for men." The score was the second highest of any among all questions. We note that "equally" could easily substitute for "as" in this statement. A strongly "undecided" upon question was in regard to 
women in the Women's Liberation Movement, although women agreeing and disagreelng balanced each other out. The women indicated a stand against militant efforts for women's rights. Summary

The questions evoking the strongest feminist responses related to equality--in child-raising, in need for education, and in making family financial decisions--and the current issues of day-care and rape. It might be noted also that the statement scoring sixth highest was "I an more concerned with personal development than I am with the approval of otbers."

The women's mean scores Indicated their feelings that (1) well-reared children are a woman's most important contribution to society; (2) militant women's rights efforts are disdainful; (3) husbands should earn wore than their wives; and (4) women are not conditioned to hide their intelligence. 


\section{B. THE INDEPEIIDENT VARIABIES *}

The independent variables used in seeking correlation with the dependent variables previously described were drawn from the tallied answers to the questions in the first two sections of the questionnaire. The first section requested basic information about the respondent and her parents. The answers indicated decisions that had been made by or for the respondent and her parents, Including decisions about school, work, marrlage, and childbearing.

The second section asked questions in reference to the respondent's life before the age of 25 ("before the age of 25 " was repeatedly emphasized). We sought answers that would provide us with information about the respondent's home life, her interests, and the intensity of her involvement in various activities. These Included school, work, athletics and sports, and politics. Two questions requested information about the roles. of the mother and father of the respondent.

\section{THE COMPOSIIE RETAIIONSHIPS}

The responses to each of the questions were grouped when necessary for stat1stical analysis. For instance, because not all of the six possible responses to the question "What is your marital status?" had enough indicated answers to be used statist1cally, we chose to divide the respondents Into two groups: those who were

* See Appendix B for tables describing the responses to each question. 
and were not widowed.

Correlations by group affiliation were not sought. However, we found that the women from the Jewish Community Center scored 23.2\% higher than the women of Holladay Park Plaza with the mean scores of the other groups arrayed in between. Table IV shows the results of our inspection and calculation of the correlations between the Independent variables. 
Independent Variables

Age

Marital

Age at Marriage

Number of Children

Education

Studies in College

Mother's Education

Father's Education

Mother's Occupation

Father's Occupation

Mother's working when a chlld

Father's Participation in

Housework

Favorite Subject in School

Participation in Athletic

Activities

Comfort with Boys during

Adolescence

Attendance at Religious Activities

Leadership in Church

Involvement in Politics

Employment Outside of Home

Type of Employment

Irave1

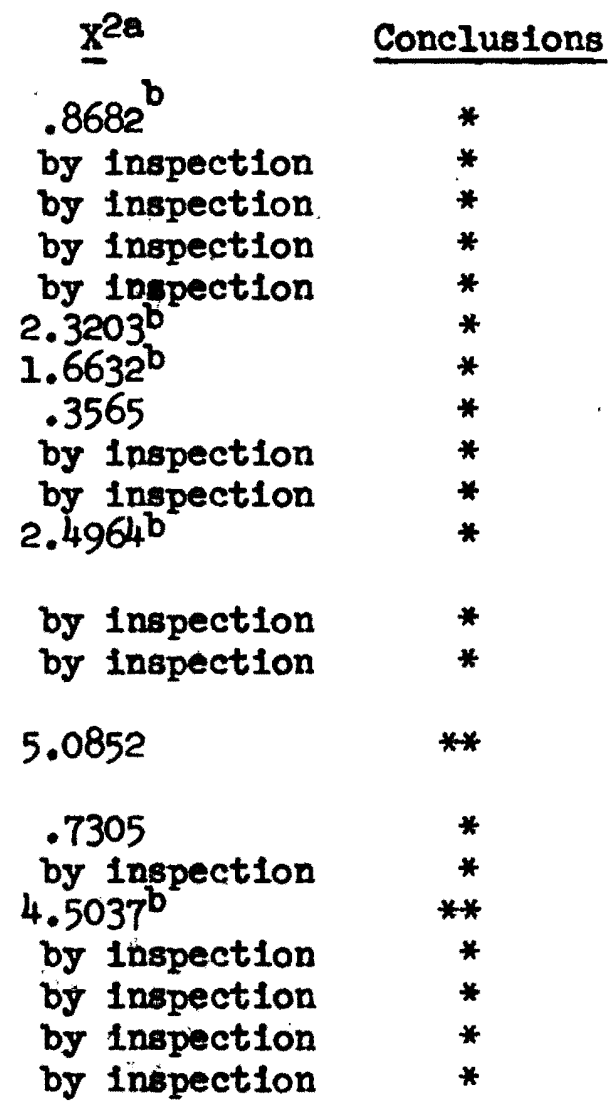

a. $a . f .=1$ in all cases; critical value, 3.841 .

b. I cell with Insufficient $N$, but association is clearly not signiflcant, or clearly significant.

* not significant.

* signiflcant at .05 level. 
By inspection, we found that of the dependent variables, as grouped, showed no correlation to the independent variables. These grouped varlables were:

1. marital status: widowed never widowed

2. age at marriage: before 20 after 20 ("never" excluded)

3. number of chlldren: one tro more then two

4. education: high school education or less education beyond high school

5. mother's occupation: homemaker other occupation ("don't know" excluded)

6. Pather's occupation: farmer or "blue collar"/craftsman "white collar"/businesisman or professional

7. father's particlpation in housework: repalrs and odd jobs, "no women's work" helped out more ("not applicable" excluded)

8. Pavorite subject in school: English or languages liberal arts or physical education sclence or th history or geogrephy ("no lavorite" excluded)

9. attendance at religlous activities: about once a month or less neexly every week or weekly more often than weekly 
10. Involvement in politics seldom or never voted usually voted.

(more involvement in politics excluded)

11. employment outside of bome:

yes

no

12. type of work:

skilled

un-or semi-skilled

professtonal

13. trave1:

very little or not at all

more travel

We tested elght of the dependent variables, using the chlsquare formula, for statistically significant correlations with the Independent variables. Six of these were not significant at the .05 level, but some shơred, to varying degrees, a tendency we chose to include in this study. We recognize that other studies, using other samples, could negate these tendencles. The critical value for these ch1-square calculations 183.841 .

1. age:

under 70

70 or older

$x^{2}=.8662$

Tendency: the younger women scored higher on the feminist attitude scale

2. studies in college:

education other studies

("no major" excluded)

$x^{2}=2.3203$

Tendency: education majors scored higher on the feminist attitude scale 
3. mother's education:

grade school or less

more than grade school

$x^{2}=1.6632$

Tendency: women whose mothers had education levels of Brede school or less scored higher on the feminist attitude scale

4. Pather's education:

grade school or 1 ess

more than grade school

$x^{2}=.3565$

Tendency: women whose fathers had education levels of grade school or less scored higher on the femintst attitude scale

5. mother's working when a child:

did work to some degree

not at all

$x^{2}=2.4964$

Tendency: vomen whose mothers worked scored higher on the feminist attitude scale

6. comfort with boys when an adolescent:

usually relaxed and at ease

not relaxed or seldom associated with boys

$x^{2}=.7305$

Tendency: women who were not relaxed or seldom assoclated with boys scored higher on the feminist attitude scale

The correlation of the independent variable with two of the

dependent variables proved significant at the .05 level when

tested with the chi-square formula.

Responses to the question of extent of participation in

athletic activities were divided between "not active or seldom 
participated," and those indicating activity to some degree. This division created a very even split among the women of our sample. We found a correlation between inactivity in athletics and abovethe-median scores on the feminist attitude scale.

We found that women who were not active participants in sports before they were 25 scored signiflcantly higher than women who did. A plrst step in trying to understand why these women were more feminlst oriented was to learn more about who they were. We decided to seek a relationship between education level and participation in sports.

TABIE V

COMPARISON OF PARTICIPATION IN SPORIS WITH EDUCAIIONAT LEVEL

less than college or trade school at least some college or trade school

Non-participants

Participants

9

17

$\mathrm{N}=48$

The result (a chi-square of 5.493, statistically significant at the .05 level with one degree of freedom) showed that most of the women who did particlpate in sports continued their education after high school. Most of the women who were not athletic did not attend high school. This may indicate that sports were emphasized 
more in college. There was indeed a feeling by some that "no physical weakling, undeveloped of muscle, deficient in nerrous control and hampered by uncorrected bodily defects can ever hope to grapple successfully with the compllcated situations of modern IIfe as they arise in a rocation, in politics, and in the give and take of stremuous social living." 4

The sports women participated in 50 years ago were not tremendously different from the sports of today. Colleges offered volleyball, hockey, track, tennis, soccer, swimming, etc. However, many of these sports had separate, less competitive rules for the "weaker sex." By the 1920's the size of bloomers had steadily decreased, and short trousers were occasionally adrocated. 5

The reasons for the lower feminist scores for the most athletic women can only be speculated. Perhaps the $32 \%$ of the women who did not finish high school and who likely missed out on sports had to help mothers with housework while the fathers did not help, and consequently did a lot of thinking about it. Perhaps non-athletic women did more reading and becams, through helghtened awareness, more feminist prone. Perbaps through their success in college, where they took physical education, some women became "Queen Bees."

4. Goodse1l, W., The Education of Women, New York: MacMillan Company, 1924, pp. 288-289.

5. Alnsworth, Dorothy S., The History of Physical Education in Colleges for Women, New York: Barnes and Company, 1930, p. 12 . 
Solid as the statistical relationship seems, the reasons are difficult to specifically determine.

Although we found no association between attendance at religlous activities and feminist attitudes, we found leadership in church to bave a statistically significant relationship. Women who took leadership roles in church scored lower than women who never or seldom took leadership roles. Although we had associated leadership, a form of assertiveness, with feminism, a consideration of what the Btble and church taught made the association more understandable. The church meant respect for tradition, submissiveness to husbands, and saw women's role as mother and wife. "As the church is subject to Christ, so let wives also be subject in everything to their husbands." 6 We should note that St. Paul gave separate orders for children and slaves. In I Corinthians; St. Paul wrote that "the head of a woman is her husband... for a man was not created for woman, but woman for man." 7

We decided, upon having come thus far in our analysis, to further compare the att1tudes of church leaders and women who were less active in churrch before the age of 25 toward the statement: "It's usually the woman's fault if she is raped." The mean score on this question was high (3.31), so we sought a dichotomy between

6. The Holy Blble, Revised Standard Version, New York: Thomas NeIson and Sons, 1959, Ephesians 5:23.

7. Tb1d., I Corinthians $11: 3$ and 11:9 
women who responded "strongly disagree" (4), and those who responded with agree, disagree, strongly disagree, or undecided $(3,2,1,0$, respectively).

TABLE VI

RESPONSES OF CHURCH LEADERS AND NON-LEADERS TO THE STATEMENT

"IT'S USUALIY THE WOMAN'S FAULT IF SHE IS RAPED"

Strongly agreed

Church leaders

Church non-leaders

$\mathrm{N}=50$
10

18
Did not strongly agree 5

17

While Insignificant statistically, the data showed that non-leaders were evenly split on the 18sue, and only $1 / 3$ of the leaders strongly agreed with the statement. This may reflect the attitude of the church toward "temptresses," and also an attitude that if the woman were home as she should be, rape would not occur. 


\section{SUMMARI AND COMCLUSIONS}

During the gathering of our data, it became evident to us that many of our hypotheses, as formally stated and as informally belleved, did not stand. It would take another study or at least perusal of other studies to find whether these hypotheses of correlations between socialization and feminist values would hold for younger women.

The majority of variables we chose had no effect upon the women's scores on the feminist attitude scale. One of these variables somewhat contradicted the findings of another study which reported that "Increased education is related to profeminist positions. "This study was based upon a 1972 Harris Poll of men and women aged 18 to over 50. With regard to education, the study found that "In general, less educated persons tend to be somewhat older, as well as more conservative, than the better educated." 8

While this study found increased education related to profeminism, it did consider chenges in schooling over the course of 50 years. Perhaps what women have been taught and who they have been taught by 18 where the difference 11 es.

Inployment outside of the home before the age of 25 was another variable which showed no correlation with feminist attitudes. Perhaps if we had asked for Information about employment and success

8. Bernard, op. c1t., p. 124. 
In improving eriplopment throughout each vonen's lifetiwe the results would have been more slgniflcant. The theory of transactional analyois suggests that women who have succeeded in their fields often fall Into the "Queen Bee Syndrome." "Queen Bees" are vomen who are highly rewarded for beling opecial, for "looking 80 fewintne" jet "thinking like a man."9

The professionally successful women are more I1kely than feminists or treditional women to be individualists, deny discrimination and to reject the assumption and goals of the roman's movement. 10

We had expected that the occupation of each woman's parents and the opportunity to travel, as an indicator of social standing, have some effect upon woman's attitude. We found no associations. Age had a silght effect upon women's fominist attitudes, but 1 ess than the Harris Poll study of women of a broader age range. That study found that "although in cross-8ection the older women vere unfformity more conservative than the younger, they had changed in a modern, rather than a traditional, direction." 11 "The effect of aging... was not to reverse attitudes or prevent change, but only to slow it down." 12

\section{Staines, G., "Queen Bee Syndrome," Psychology Today,} VII, No. 8 (Jamary 1974), pp. 55-56.

10. Ibid., p. 58 .

11. Bernard, og. c1t., p. 122 .

12. Ibid., p. 121 . 
Our findings vere in accordance: jounger women scored hlgher.

Women iho mojored in education scored higher than women who pursued other studies in college and trede school. In particular, we expected that wowen vho studied more analytical studies wight score higher than education wajors. Forrever, an Inspection of the dats shows that the corverse is true. We can only speculate, but we feel that education ajors mey have scored higher because after graduation they vere prepared to go into a profession that was open to women, and where they way have had lengthy careers.

We found that mother's education had a Breater affect upon the scores of the women than did father's education. Also, scores were affected by wothers who worked or did not work when the women were children (working mothers vere assoclated with higher scores on the scale), but unaffected by the participation of fathers in hoisework. It might be simply sald that romen's mothers had greatex Infuence upon then than their fathers.

Oar research has truly been a learning experience. Many of the lessons have been technical ones concerning the research process. Some of the lessons have been in judgement. We have soundly realized that our world of social workers and other "belping" professionals is not representative of the world at large, and ve have learned the necessity of dolng a more thorough study of all posstble angles before judging or making hypotheses. The connections between the younger and oldex jears of women's ilves, we found, do 
In fact exist, but they are far more complicated than we presumed. The more important lessons cannot be adequately described. From each woman the met we gained an awareness of the experience of being a woman in a male-dominated soctety during decades of struggies for that soclety's reform. The lessons were laced with bitterness and veariness, but also Included a messure of hope. 
Ainsworth, Dorothy S. The History of Physicel Education in Colleges for Women. New York: A.S. Barnes and Company, 1930.

Bardwick, Judith M., and Elizabeth Douvan. "Ambivalence: The Socialization of Women," Woman in Sexist Soclety, ed. V. Gornick and B.K. Moran. New York: Baslc Books, Inc., 1971, pp. 225-241.

Beauvolr, Simone de. The Second Sex. New York: Alfred A. Knopf, Inc., 1952.

Bernard, Jesse. "Age, Sex; and Feminism." The Annals of the American Academy of Polltical and Soc1al Science, CDXV September 1974, pp. 120-137.

Brovermann, Inge K., et, al. "Sex Role Stereotypes: A Current Appra1sai." Journal of Soc1al Issues, XXVIII, No. 2 (1972), pp. 59-78.

Dunkle, Ruth E. "Life Experiences and Adjustment of Women to Aging." (Unpublished paper presented at the Gerontological Soclety's 25th Annual Scientific Meeting, San Juan, Puerto Rico, December 1972).

Gump, Janice Porter. "Sex Role Attitudes and Psychological Well-Being." Journal of Social Issues, XXVIIII, No. 2 (1972), pp. 79-92.

The Holy Bible. Revised.Standard Version. New York: Thomas Nelson and Sons, 1959.

Joestung, Joan. "Comparison of Women's Liberation Members with their Non-Member Peers." Psychological Report, Part 2 (December 1972), pp. 129-134.

Rabin, Joy Spaulding, Margaret E. Kuhr, and Susan Landau Marker. "The Liberation of 01der Women." (Unpublished paper presented at the Gerontological Society's 26th Annual Sclentific Meeting, Miami Beach, Florida, November 1973).

"The Right to Choose - Alternatives for Women Opinionaire." American Association of University Women Journal, LXIII, î́. 2 (Jamuary 1970), pp. 73-74.

Sangor, Susan and Henry A. Alker. "Dimensions of Internal-External Local or Controller in the Women's Lfberation Movement:" Journal of Soc1al Issues XXVIII, Ho. 2 (1973), pp. 115-129. 
Staines, Grabam, et. al. "The Queen Bee Syndrome." Paychology Today, VII, No. 8 (January 1974), pp. 55-60.

Stelmann, Anne. "Cultural Values, Female Role Expectations, and Therapeutic Goals: Research and Interpretation," Women in Therapy, ed. Franks, Violet and Vasanti Buxtle, New York: Brunner-Mazel, 1974, pp. 51-82.

Torr1s; Carol. "Woman and Man." Psychology Today, V. No. 10 (March 1972), pp. 82-85.

Torris, Carol. "Woman and Man: A Psychology Today Questionna1re." Psychology Today, IV, No. 9 (February 1971), pp. 82-88. 


\section{APPIIDIX A}

THE QUESTIOMRATRE

Group

1. What is your age?

2. What is your maxital status? (check one) single

- married vidowed

divorced separated other

3. At what age were you first married?

4. If you have had chilldren, how many have you had?

5. How far did you go in school? (check one) did not finish grade school finished grade school some high school lintshed high school some college or trade school finiahed college or trade school graduate school degree:

6. If you attended college or trade school, what did you study?

7. How far did your parents go in school? mother Pather

8. What were your parents' specific occupations? mother father

The following questlons refer only to your life BEFORE IHE AGE OF TWEMTIY-FIVE:

1. DId your mother work when you were a chlld? (check one) full-time throughout part-time, or full-time on and off did not work while her children were young, but did work later not at all 
APPEADIX A

2. What ald your father do around the house? (check one) repalrs and odd jobs; no "wowen's work" helped out occasionally with housohold tasks shared equally in most household tesks ald most or 211 bousehold taske not applicable

Please remember, all of the questions on this page refex only to your life BEFORE THE AGE OF TWISTIS-ITVE:

3. What was your favorite subject in school?

4. How active were you in aports or athletic activities? (check one) not active or seldom participated moderately active very active, on a regular basis

5. How comfortable did you feel with boys during jour adolescence? (check one) usually uncomfortable and uneasy usually relaxed and at ease seldom associated with boys then

6. How often did you attend religious activities? (check one) almost never about once a month or 1 ess nearly every week or veekly more often than weekly

7. Did you take and leadership roles in your church? (check one) never

seldom often

8. How involved were you in politics before you were twenty-five? (check one) seldom or never voted usually voted usually voted, and was involved in party or campaign vork usually voted, was involved in party or campaign work, and vas a candidate noself

9. Did you work outside of your home for wages? no. yes What kind of work? 
APPIADIX A

10. Did you travel for pleasure? (check one) not at all very little; just close to home within the United States vithin the continent of llorth America outside of the continent

We would like to know your current opinions of the following statements. Please indicate your feelings by circling the letters to the left of each statement, according to whether Jou:

$$
\begin{aligned}
& \text { SA SYRORGLY AGREE } \\
& \text { A ACREAE } \\
& \overline{0} \text { UNDECIDED } \\
& \bar{D} \text { DISAGRER } \\
& \text { SD SIROIRTI DISAGRES }
\end{aligned}
$$

SA A U D SD 1. I don't belleve wowen should be clergy.

SA A U D SD 2. Husbands should earn more money than their wives.

SA A U D SD 3. A working mother can establish just as strong and secure a relationship with her children as can a stay-at-home mother.

SA A U D SD 4. Women do not think as logically as men.

SA A I D SD 5. Wives should share equally with their husbands in making family financial dectsions.

SA A U D SD 6. We need more tomen politicians.

SA A U D SD 7. Boys have a greater need for athletlc programs in school than do girle.

SA A U D SD 8. Childratsing should be an equally shared responstbility of husband and wife.

SA A U D SD 9. I an more concerned with my personal development than I am with the approval of other 8 .

SA A U D SD 10. I see a great need for Inexpensive day care ceuters for children. 
APPEADIX A

SA A U D SD 11 . Employed women probably have less satiafying marriages.

SA A U D SD 12. It's usually the woman's fault if she is raped.

SA A U D SD 13. Women in the Women's Ifberation Movement are well-adjusted women with justiflable causes.

SA A U D SD 14. A woman can make no greater contribution to society than the successful rearing of normal, well-adjusted chtldren.

SA A U D SD 15. A marriage can be very complete without children.

SA A U D SD 16. Women are much better off than men in this society because they have protection, lelsure, and freedom from pressures to achieve.

SA A U D SD 17. For a woman nowadays, it is marriage whlch gives her her sense of Identity and a respected place in society.

SA A O D SD 18. Single women should have the chotce to bear and or adopt children without social rejection.

SA A U D SD 19. Women are conditioned to hide their intelligence.

SA A $O$ D SD 20. Militant efforts for women!s rights will do more harm than good.

SA A U D SD 21. Women are more emotional than men.

SA A U D SD 22. Woman's image in the mass media overly emphasizes beauty, fashions, and home-making virtues.

SA A U D SD 23. Education is as important for women as for men.

SA A U D SD 24. Women don't need to have credit in their orm names if they are married.

THAITK YOU FOR YOUR COOPERAIION!!! 


\section{APPERIDIX B \\ RESPOKSES TO BASE DATA ITHUS}

"Group" :

number

Jewish Community Center Marshall Center Loaves and Fishes Lake Oswego Sentor Center Holladay Park Plaza

$\begin{array}{r}8 \\ 5 \\ 17 \\ 8 \\ 18 \\ \hline n=50\end{array}$

"What is your age?", (categorized) :

number
$65-69$

$70-74$

$75-79$

$80-84$

85-89

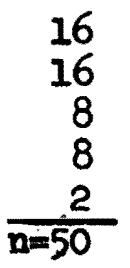

16

8

$\frac{2}{n=50}$

"What 1s your marital status?" :

number

widowed

marriled

single

divorced

separated of of total

16.0

10.0

22.0

16.0

36.0

$\frac{36.0}{100.0}$ mean score

65.38

62.20

59.72

59.13

53.06

of of total

$$
\begin{array}{r}
32.0 \\
32.0 \\
16.0 \\
16.0 \\
4.0 \\
\hline 100.0
\end{array}
$$

"At what age were you first marrled? ":

never

before 20

$20-24$

25-29

after 29 number
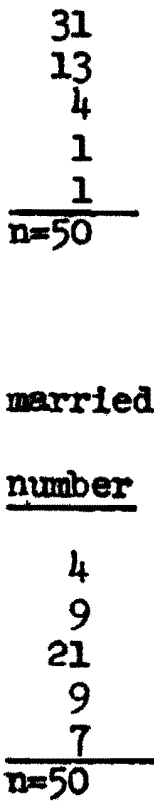

\& of total

$$
\begin{array}{r}
62.0 \\
26.0 \\
8.0 \\
2.0 \\
2.0 \\
\hline 100.0
\end{array}
$$

of of total

$$
\begin{array}{r}
8.0 \\
18.0 \\
42.0 \\
18.0 \\
14.0 \\
\hline 100.0
\end{array}
$$


APPFIDIX B

"If you have had children, how many have you had?", (categorized):

number

1
2
3
4
5
6
\& of total

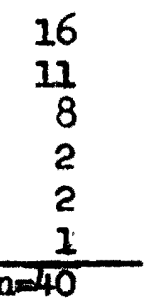

40.0

27.5

20.0

5.0

5.0

$\frac{2.5}{100.0}$

"How far did you go in school?" :

\begin{tabular}{cc} 
number & \& of total \\
\hline 5 & 10.0 \\
4 & 8.0 \\
7 & 14.0 \\
9 & 18.0 \\
13 & 26.0 \\
10 & 20.0 \\
$\frac{2}{n=50}$ & 4.0 \\
& 100.0
\end{tabular}

If you attended college or grade school, what did you study?", (categorized):

did not f1ntsh grade school

fInished grade school some high school

IInished high school

some college or trade

school

Pintshed college or trade

school

graduate school degree

education

trade (secretarlal)

Itberal arts (lenguage, music)

sclences (math, peychology, 5

mursing)

no major number

8

5

\& of total

31.0

27.5

17.2

17.2

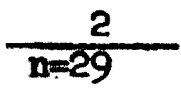

$\frac{6.8}{100.0}$ 
APPEIDIX B

How far did your parénts go in school?", (categorized):

MOHEER

FATHER

\begin{tabular}{|c|c|c|c|}
\hline number & of of total & number & \& of total \\
\hline 18 & 36.0 & 16 & 32.0 \\
\hline $\begin{array}{r}19 \\
2 \\
9 \\
1\end{array}$ & $\begin{array}{r}38.0 \\
4.0 \\
18.0 \\
2.0\end{array}$ & $\begin{array}{r}17 \\
4 \\
8 \\
4\end{array}$ & $\begin{array}{r}34.0 \\
8.0 \\
16.0 \\
8.0\end{array}$ \\
\hline 1 & 2.0 & 1 & 2.0 \\
\hline$\frac{0}{=50}$ & $\frac{0.0}{100.0}$ & $\frac{0}{n=50}$ & $\frac{0.0}{100.0}$ \\
\hline
\end{tabular}

"What were your parents' apec1fic occupations?", (categor1zed):

MOTHERR

FATHER

did not finish grade school

PInished grade school some high school finished high school some college or grade school.

IInished college or grede school

graduate school degree

\section{MOTHAR}

\begin{tabular}{|c|c|c|c|}
\hline number & \& of total & number & of of total \\
\hline $4 \frac{1}{5}$ & $\begin{array}{r}2.0 \\
82.0 \\
10.0\end{array}$ & $\begin{array}{r}3 \\
12 \\
22\end{array}$ & $\begin{array}{r}6.0 \\
24.0 \\
44.0\end{array}$ \\
\hline 2 & 4.0 & 10 & 20.0 \\
\hline$\frac{1}{n=50}$ & $\begin{array}{r}2.0 \\
100.0\end{array}$ & $\frac{3}{n=50}$ & $\frac{6.0}{100.0}$ \\
\hline
\end{tabular}

"Dild your mother work when you were a child?":

"don't know"

homemaker or farmer

"blue collar,"

craftsperson

"white collar,"

bustnessperson

professional number

not at a.11

did not work while her

children were young, but

did work later

part-time, or full-time

on and off

full-time throughout
37

6

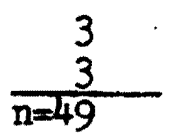

of of total

75.5

12.3

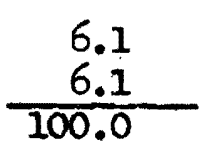

Note: one woman did not know, and was excluded from the tabulation. 
APPERIDIX B

"What did your father do around the house?":

number

of total

repairs and odd jobs; no

"women's work".

$22 \quad 44.0$

helped out occeslonally with

household tasks

12

24.0

shared equally in most household

tasks

\begin{tabular}{rr}
2 & 4.0 \\
0 & 0.0 \\
14 & 28.0 \\
\hline $\mathrm{n}=50$ & 100.0
\end{tabular}

"What was your favorite subject in school?", (categorized):

did most or all household tasks

not applicable

number

of of total

Bnglish or languages

Itberal arts or physical

education.

14

28.0

science or math

11

history or geogrephy

11

22.0

no fevorite

10

22.0

$\frac{4}{n=50}$

20.0

$\frac{8.0}{100.0}$

"How active were you in sports or athletic activities?":

number

$\begin{array}{r}18 \\ 8 \\ 24 \\ \hline n=50\end{array}$ of of total

moderately ective

very active, on a regular basis

not active or seldom participated

"How comfortable did you feel with the boys during your adolescence?":

number

of of total

usually relaxed and at ease seldom assoclated with boys then usually uncomfortable and uneasy

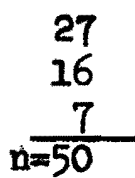

54.0

32.0

$\frac{14.0}{100.0}$ 
APPENDIX B

"How often did you attend religious activities?":

number

nearly every week or weekly more often than weekly about once $a$ month or 1 ess almost never

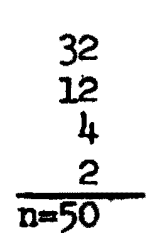

o of total

64.0

24.0

8.0

$\frac{4.0}{100.0}$

"Did you take anj leadership roles in your church?":

number

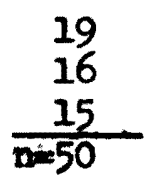

of of total

seldom

often

never

"How involved vere you in politics before you were twenty-five?":

number

32

17

1

$\frac{0}{n=50}$ of of tatál

$$
64.0
$$$$
34.0
$$

seldom or never voted
usually voted, and was involved

in párty or campaign work usually voted, was involved in party or campaign work, and wes a candidate myself

$$
\begin{array}{r}
38.0 \\
32.0 \\
30.0 \\
\hline 100.0
\end{array}
$$

"Did you work outside your home for wages?":

$$
\text { number }
$$

yes

no

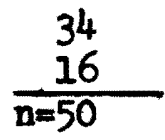

of of total

68.0

$\frac{32.0}{100.0}$ 
APPEIDIX B

"What kind of work?", (categorized):

skilled, secretary, clerk, beautician professional un- or semi-skilled, laborer, maid

"Did you travel for pleasure?":

number

very little; just close to home within the UnIted States within the continent of North Americe. outside of the continent not at all

28

14 number

of of total

$\begin{array}{cc}13 & 40.6 \\ 12 & 37.5 \\ \frac{7}{n=32} & \frac{21.9}{100.0}\end{array}$

$\begin{array}{r}3 \\ 2 \\ 3 \\ \hline n=50\end{array}$
56.0

28.0

\& of total

$\begin{array}{r}6.0 \\ 4.0 \\ 6.0 \\ \hline 100.0\end{array}$

